\title{
US hegemony and Sino-Russia energy security cooperation
}

\author{
Pang Changwei ${ }^{1, *}$, Zhou Xiaojia ${ }^{2}$, and Sun $\mathrm{Lu}^{1}$ \\ ${ }^{1}$ China University of Petroleum, Beijing, China \\ ${ }^{2}$ Fudan University, Beijing, China
}

\begin{abstract}
Why China and Russia give up previous suspicious attitudes toward each other, and going toward close cooperation on Energy security? We argue the threat of American hegemony push China and Russia together. Facing US sanction and strategic pressure, Russia changed its perception about China, and regarded China rise as opportunity. As a consequence, Russia strengthened its ties with China, and completed the oil pipe line which favored China. In addition to this, Russia permitted China Energy company access to its upstream and downstream Energy industry. With the rise of China, the structural conflict between China and US intensified. Trump administration explicitly described China as adversary. The fact that China's energy transportation line is under the control of US Navy is a source of vulnerability. Out of consideration of reducing risk of cutting off energy supply, China developed a close cooperation with Russia on Energy safety.
\end{abstract}

\section{Introduction}

As neighboring countries, China and Russia had deeper grievances in the history of bilateral relations and had strong doubts about bilateral energy cooperation [1]. As a consequence, they achieved little in the progress of energy cooperation before 2008. Russia initially did not attach importance to the energy exports to the China in the east. After 2008, Sino-Russia energy security cooperation achieved a lot in the terms of the amount of contract and depth. In 2017, Russia became the No 1 oil exporting country for China, and Chinese capital also successively entered the upstream and downstream of Russian energy industry. The natural gas pipeline to China also completed more than half. Putin clearly pointed out that Russia should regard China's rise as opportunity, not threat. Some scholars argue Sino-Russia energy cooperation has entered a stage of strategic partnership. For China, importing oil and gas from Russia is not the best choice, because China buys energy from Russia at the price above the international market level. At current stage, China could obtain energy from Middle East and Central Asia at reasonable price. Why Russian and China give up their realistic consideration, and choose to cooperate on energy security?

Based on theory of energy security, we argue the dynamics of Sino-Russia cooperation is based on the common threat of US Hegemony. Although, Previous American

\footnotetext{
* Corresponding author: pangcw@126.com
} 
administration shows their willingness to cooperate with China, they never forget containing China's influence. After Trump took office, he regarded China as explicit threat and adopted zero sum approach toward Sino-US relations. As the majority of China's energy importation is through sea lane which is under the control of US and its allies, China spare no effort to diverse its importation of oil, in the hope of avoiding cut off energy supply in case of conflict with US. To defend its geopolitical influence sphere, Russia launched military intervention into Ukraine. As a result, Russia suffered the sanctions by US and its western allies. Diversification its energy exportation becomes the high priority of Russia Energy strategy agenda. China and Russia develop a comprehensive and deep cooperation relationship on Energy safety.

This article can be divided into four sections. In the first section, we define energy security through discussion. In the second section, we describe and analyze the motivation of cooperation of Russia and China. In the Third section, we introduce the progress of SinoRussia Energy cooperation. The fourth section summarizes the full article.

\section{Define Energy safety}

Thomas argues Energy safety involves economic, political, military, strategic security. The so called economic security means the state has sufficient resource, which also means state can access to goods and service at affordable price. Political security means maintaining domestic stability; strategic and military security refers to the military capability to detect threat and confront threat [2]. He argues that the oil crisis of the 1970s hit these three kinds of security. Oil shortages and soaring oil prices caused widespread inflation and caused Western countries to fall into economic crisis and political turmoil. Arms suppliers in industrialized countries have sold weapons to Middle Eastern countries in exchange for more Middle Eastern oil, threatening the military balance between the Arab countries and Israel, which led to a new round of arms race. At the same time, industrialized countries have chosen to strengthen their naval forces in order to protect the oil sources of international trade and transportation corridors. Daniel Yekin pointed out that "the goal of energy security is to ensure an adequate and reliable energy supply at reasonable price without compromising the country's main values and goals" [3]. Energy security includes not only the normal operation of the national economy, but also ensuring that the military force can obtain a reliable fuel supply to safeguard the country's vital interests. Paul B. Stares summarized the above traditional energy security theory. He argues that traditional energy security concerns focus on the sudden suspension of existing energy supply agreements, Security threats caused by price by manipulation. Correspondingly, potential security threats such as political turmoil, economic threats, military conflicts and terrorist attacks are the most important traditional concerns. These safety concerns include not only the source of energy supply, but also the routes and means of energy transportation. Therefore, evaluating the level of energy security is, to a large extent, assessing whether a country is dependent on a certain type of energy, whether a country acquired energy in its territory, or whether a country's energy need must be meet by importation. If its energy consumption has to rely on importation, then energy security involves the dependence on foreign energy sources, the diversification of energy sources, and the political turmoil or enemy control in the source.

\section{Indo-Pacific strategy and China Energy security}

Indo-Pacific strategy is ideology oriented with its emphasis on confrontation, zero-sum game approach [4]. It originated from Japanese Prime minister Abe's "Value diplomacy", 
which argue Asia Pacific countries with similar value and political regime should form coalition to strengthen security and economic cooperation, maintain international rule, and counter the rise of China. State secretary Tillerson argues, Indo-Pacific strategy geography scope should include Indian Ocean and Pacific Ocean, while Japan and Indian held the key strategic position in this strategy. He claim China's Economic diplomacy undermine the freedom and sovereignty of developing countries. In response, US should provide developing counties with alternative finance mechanism. In addition, the 2017 US National Defense Strategy Report regards China as revisionist country that challenges US hegemony and undermines US security and prosperity. The 2018 US national defense strategy report continue the tone of 2017 National Defense strategy Report, describing China as an adversary, emphasizing Confrontation and Zero-sum game perspective. Both reports argue US Indo-pacific strategy should strengthen alliances, establish a security framework to deter China's invasion, ensure stability of Asia-Pacific area, Freedom navigation on the high seas.

Trump's Indo-Pacific strategy has deviated from the basic positions of previous US government's China policy. Both Bush administration and Obama administration China policy emphasize containment and cooperation. In the multilateral mechanism, the US tries to include China as much as possible. But Trump's Indo-Pacific strategy emphasizes zerosum game approach, regards China as adversary, ignore China's contribution to the regional and world economy, and ignores the contribution of China's AIIB and the "Belt and Road" construction to infrastructure construction in developing countries. Because the strategy emphasizes confrontation with China, it is difficult for China to cooperate with United States on the DPRK nuclear issue, the Iranian nuclear issue and climate warming issue.

\section{Country's reaction to the indo-pacific strategy}

The attitudes of the core countries of India-Pacific strategy are inconsistent with the United States. Although India supports US in its posture, it retains its view on the strategy. First of all, Indian stick to its non-alliance tradition and consistently opposed the adoption of alliances against third countries. Second, India thinks Indo-pacific strategy reflects US strategic value, not Indian strategic value. India thinks the geographic scope of Indo-pacific strategy is not large enough. India's strategic influence is not limited to the Indian Ocean, but originates in Malacca and goes directly to the Middle East. India believes that the strategy emphasizes the containment of China, which is not in the interest of India. India believes that India lags behind China in both economic and military strength and is unwilling to be the main force against China. Cooperation with China is conducive to India's development. Finally, on the issue of exclusive economic zone, India and China hold a similar position. India also believes that foreign warships entering the exclusive economic zone of a country should obtain the consent of the country in advance.

Japan basically supports the anti-China stance of the Indo-Pacific strategy, but it is limited in its support. First of all, Japan has a heavy dependence on the Chinese economy. To some extent, Japan has some kind of vulnerability to China. Second, the Japanese people opposed the revision of the peace constitution, which prohibits Japan act as a normal country and jointly carry out military operations with the United States in the Asia-Pacific region. The above two points have determined that Japan is unlikely to take a proactive and open military confrontation against China.

Australia, the Philippines, South Korea, Thailand have close economic ties with China. The economic growth of these countries is partly driven by the Chinese economy. The Philippines has territorial disputes with China, but it seeks Chinese capital. South Korea has sought China's help in the DPRK nuclear issue, and Thailand has been deeply integrated 
into the Chinese economic circle. All Southeast Asian countries are reluctant to choose sides, because it is not in the interest of these countries. A safe and stable external environment is a necessary condition for the economic development of all countries in the region. Finally, Cambodia and Laos, which have close ties with China, explicitly refused to join any alliance against China.

Trump's Indo-Pacific strategy has a strong ideological color, emphasizes confrontation, and views Sino-US relations in a zero-sum approach. This is not in line with the desire of most developing countries in the Indo-Pacific region which cherish development and stability. Constrained by their own national interest, the core countries of the strategy, like India, Australia, and Japan, can only provide limited support for Indo-Pacific strategy. No country is willing to play active role in confronting China. The key to the successful implementation of the India-Pacific strategy is whether the United States can persuade its allies to fight against China.

From the current point of view, it is difficult for US to implement Indo-Pacific strategy, because neither its allies nor the small countries in the region are willing to fully confront China. Therefore, the safety of China's energy transportation sea lane depends mainly on Sino-US relations. As long as there is no direct military conflict between China and the United States, the United States will not attack Chinese oil carriers or block the Strait of Malacca against China. The Sino-US trade war and the Indo-pacific strategy will have great impact on the Sino-Russia relationship, Sino-US relationship, and Russia-US relationship. Under the pressure of the United States, China and Russia may form a quasi-alliance of military and politics, unite against the United States, and jointly resist the pressure of the United States and NATO.

\section{Motivation behind Russia approaching China}

Due to historical reasons, Russia has deep security concerns about China. Russia worried that China-Russia energy cooperation will facilitate China's economy which will transform into China's relative advantage toward Russia. Such concern play important role in Russia's decision on Sino-Russia energy cooperation. Before 2008, oil and gas cooperation between China and Russia achieve little progress. Around the route of oil and gas pipelines, China and Russia negotiated for a long time, and do not reach a deal. The amount and number of Sino-Russia energy contracts are relatively small. At that time, the Russian energy market was centered on Europe, while the economic construction in the Far East was backward. The Far East demand for energy was not large, and it was not the focus of Russian oil and gas development. However, the U.S.-led NATO has eroded Russia's geopolitical interests, resulting in changes in Russia's interest calculation in Sino-Russia energy cooperation.

On August 8, 2008, "five day war" broke out and Russian military intervened in Georgia. Due to military intervention in Georgia, Russia was sanctioned by the United States and Europe. Coupled with the decline in oil prices in the international market, Russia, which relies heavily on energy exports, suffered significant economic losses. At this point, Russia began to turn its attention to the East, seeking to diversification of its energy exportation. Russia allowed Chinese capital to enter upstream oil and gas energy industry which is previous forbidden, and the oil pipeline to China was finally completed. Putin began to see China's rise as an opportunity, not a threat [5]. In 2012, Putin re-elected as president. Based on the judgment of the international situation, he repeatedly emphasized the "eastward strategy" and improved the strategical level of Sino-Russia cooperation. Now, China has become the most important buyer in the Asian market for Russia. The completion of the oil pipeline to Daqing has further consolidated China's position in the Russian energy Asia strategy. 
After the outbreak of the Ukrainian crisis in 2014, Russia's relation with NATO continued to deteriorate, and Russia cooperation with NATO virtually stopped. In September 2015, Russia got involved in Syria civil war. The Syrian issue became another tipping point for Russia-West relation. In order to punish Russia, the US-led NATO jointly launched economic sanctions. Europe also continuously reduced its dependence on Russia's oil. The continuous development of shale oil technology has made the United States more capable of suppressing oil prices, which caused Russia to suffer major economic losses [6]. In response, Russia accelerated the pace of diversification of energy exports and signed a series of oil and gas cooperation contracts with China. Economic sanctions make it difficult for Russia to obtain Western capital and technology, which also creates opportunities for Chinese capital to enter Russia's oil and gas industry in depth. Until 2015, China has become Russia's largest oil buyer, and China imported more than 800,000 barrels of oil per day from Russia.

After 2008, Russia, which has been continuously sanctioned and suppressed by the United States, has gradually accepted China as a strategic partner. In order to ensure the safety of energy exports that are related to its economic lifeline, Russia has adopt long term perspective toward Sino-Russia energy cooperation, choose the direction of the oil pipeline with priority to China, and sign a large number of long-term contracts with China to allow Chinese capital to enter its upstream and downstream oil and gas industry. Russia and China have formed a strategic partnership in the energy sector [7].

\section{Motivation behind China approaching Russia}

China is full of doubts about the US-led international energy order. As a beneficiary of the current international order, China's economic rise benefits a lot from the US-led international energy and security system. However, because China's political regime is different from that of Western countries. The Western countries represented by the United States are full of doubts about China's rise. In order to prevent the lifeline of energy from being controlled by others, China has done its best to diversify its energy import channels, strengthen cooperation with Russia which is an energy powerhouse, and try to establish an international energy system that is independent of the United States.

With the rise of China, the structural contradictions between China and the United States have become increasingly prominent. In 2010, China overtook Japan to become the world's second largest economy. Due to the rapid economic development, China's military modernization has also begun to accelerate. In the South China Sea dispute, China changed its diplomatic strategy, from the past "keeping a low profile" to "striving for a achievement". China no longer endured the violation of China's maritime rights by Southeast Asian countries, and actively defended its rights. In order to access overseas markets and ensure the resources needed to develop the economy, China actively cooperates with third world countries to achieve mutual benefit and win-win results. The Chinese model has also been seen as an alternative to the development path of the West, and more and more underdeveloped countries have tried to follow suit. Since energy cooperation between China and the third world countries does not include ideology, there are no preconditions, and the third world countries have financing channels other than Western countries. All of this is seen by the West represented by the United States as a challenge to its hegemony and ideology.

China's energy security is very vulnerable. First, China has become biggest consumer in terms of oil and gas in the world, but the self-supply rate is not high, and most rely on imports. Second, a large part of China's oil and gas imports come from the Middle East, and oil and gas transportation from the Middle East must pass through the Indian Ocean and the Straits of Malacca. With the current naval strength, China cannot guarantee the safety of its energy channel in the possible Sino-US military confrontation. Finally, if China's energy imports rely on Western-led international energy markets, there will be great risk out of China's control. 
The energy cooperation between China and Russia has strategic implication, as energy cooperation can further strengthen the strategic mutual trust between China and Russia. As one of the few socialist countries in the world, China's political system has been criticized by Western countries. Similarly, Russia's choice of its national development path is also seen by the West as a heresy. China and Russia share common interests in safeguarding the autonomy of the country's development path. Secondly, in response to China's rise, the United States launched a strategic containment toward China, increased security cooperation with ASEAN countries, frequently conducted exercises in the South China Sea to demonstrated its power to deter China.

Russian geopolitical influence sphere has also been undermined by US led NATO, and Russian Middle east ally Syria also suffer the suppression of western countries. In order to strengthen Sino-Russia tie, Russia supports China's "One Belt, One Road" initiative and is willing to link the "Eurasian economy" with the "Silk Road Economic Belt". China and Russia have common position on the denuclearization of the Korean Peninsula, the development of Arctic resources and the use of waterways of Arctic.

In fact, China is cooperating with Russia to establish an energy security system that is different from the West. First, at the United Nations, China stand in line with Russia to give support to the third world oil producing countries (Iran, Venezuela, and Sudan) that were excluded by the West, and to veto Western sanctions on these countries. Second, China has obtained Russian understanding and acquiescence, established close energy cooperation with Central Asian countries [8]. In order to prevent US influence from entering Central Asia, China and Russia reached a tacit agreement to establish a Shanghai Cooperation Organization. It is worth noting that the organization may also discuss the possibility of accepting the oil producing country Iran as its member state.

\section{Sino-Russia cooperation on energy security}

After 17 years growth of energy consumption, China has become World biggest crude oil consumer. In 2017 China accounted for $33.6 \%$ of the total world Energy consumption growth. China has surpassed US becoming No 1 oil importing country in the world. The Chinese importation of oil reached 3.96 hundred million tons, increased $10.8 \%$ compared with last year. The percent of imported oil account for total china oil consumption increased 3 percent, and reach $67.4 \%$. In 2017 Sino-Russia crude oil trade reached 59.8 million tons, and refined oil trade reached 2.1 million tons, total up 6.19 hundred million ton. The top five China's oil importation countries were Russia, Saudi Arab, Angola, Oman. Russia is one of the world biggest countries in terms of Oil and gas reservation, production, and exportation. In 2017, Russia has oil and gas reservation about 14500 MT oil and 35 trillion cubic meters, which account for $6 \%$ and $18.1 \%$ of world reservation; In 2017, Russia oil production and gas production are 554.4 Million Ton, 635.6 billion cubic meters. Russia Exportation oil and gas are $423.8 \mathrm{MT}$ and 230.9 billion cubic meters. (please see Table).

Table. China Energy consumption and importation in 2017

\begin{tabular}{|c|c|c|c|}
\hline Category & $\begin{array}{c}\text { Oil } \\
\text { (Unit: million tons, } \\
\text { increase) }\end{array}$ & $\begin{array}{c}\text { Gas } \\
\text { (Unit: one hundred } \\
\text { million cubic meters, } \\
\text { increase) }\end{array}$ & $\begin{array}{c}\text { LNG } \\
\text { (Unit: one hundred } \\
\text { million tons, increase) }\end{array}$ \\
\hline Consumption & $608.4(+3.9 \%)$ & $2404(+15.1 \%$ & \\
\hline Production by China & $191.5(-3.8 \%)$ & $1492(+8.5 \%)$ & \\
\hline LNG importation & & & $39(+48.4 \%)$ \\
\hline Importation from & 4.3 & 362 & \\
\hline
\end{tabular}




\begin{tabular}{|c|c|c|c|}
\hline Central Asia & (oil through pipeline) & (gas through pipeline) & \\
\hline $\begin{array}{c}\text { Importation from } \\
\text { Russia }\end{array}$ & $59.8(+14 \%)$ & & 0.44 \\
\hline
\end{tabular}

Data Source: BP World Energy Outlook 2018, China Custom

Russia turned its energy focus to the Far East area. Prime Minister Putin ratified Russian "2030 energy strategy" at November 13, 2009. According to the strategy, energy exportation to Asian market will account for 26\%- 27\% of total Russia energy production by 2030 . Russia will speed up oil and gas exploitation of East area, and energy cooperation with China becomes top priority of Russia energy diplomatic agenda. In this document, Russia emphasizes the world class energy power status, and the ability to control risk of International energy market, establishes an International energy system independent of Western countries, and tries to diversify its energy exportation.

On April 13, 2009, then Prime Minister Putin presided over a government meeting which approved the agreement on Sino-Russia cooperation in the oil field. Putin said that the agreement to build the Eastern Siberian-Pacific oil pipeline which connects with China's regional line will create a "stable and reliable market" for the sale of Eastern Siberia oil to the East. On April 21, 2009, China and Russia signed a set of agreement, like the "Intergovernmental Agreement on Sino-Russia Cooperation in the Field of Petroleum," and "cooperation agreements on Sino-Russia oil pipeline construction", "300 million tons of crude oil trade", and "\$25 billion oil loan" etc. The move marks a major breakthrough in energy cooperation between the two countries. The agreement stipulates that Russia will supply 15 million tons of crude oil to China through pipelines within 20 years from January 1, 2011. In March 2013, Russia agreed to increase the supply of pipeline crude oil to 30 million tons per year. As a response, China initiated the construction of the Mohe-Daqing oil pipe line as supplement.

The Sino-Russia crude oil pipeline has been fully expanded to increase transportation capacity. On January 1, 2018, China opened the inlet valve of Mohe Oil Station. Russian crude oil entered the second line of Sino-Russia crude oil pipeline and began to transport Russian crude oil from Mohe to Daqing Linyuan Refinery. The amount of pipeline oil imported from Russia will increase from 15 million tons per year to 30 million tons per year.

On June 8, 2018, PetroChina and Gazprom (hereinafter referred to as the Russian Gas Company) signed the Supplementary Agreement on the Mutual Recognition and Cooperation Agreement on Standards and Conformity Assessment Results, marking the cooperation in the field of standard identification and mutual recognition. An important step has been advanced to help promote mutual recognition of national and industry standards between the two countries and to avoid repeated testing of products of mutual interest. At present, the construction of the Sino-Russia East Line natural gas pipeline project is progressing smoothly. Gazprom said that it is willing to cooperate with PetroChina to promote the Sino-Russia East-line natural gas pipeline, the Far East supply of gas to China, and underground gas storage, and so on, to create more economic and social benefits for both sides.

In the context of the Ukrainian crisis and the United States, Europe and Japan jointly sanctioning Russia to withdraw the Crimean Peninsula, on May 21, 2014, China and Russia reached a long-term natural gas contract about Eastern line worth US $\$ 400$ billion. The contract period is 30 years, 38 billion Cubic meters per year, the gas price is linked to the price of oil. According to the contract, China and Russia will invest 70 billion U.S. dollars to build infrastructure. The Chinese side will pay an advance payment of 25 billion U.S. dollars. During President Putin's visit China in October 2004, PetroChina signed a strategic 
cooperation agreement with the Gazprom. At this time, Sino-Russia gas cooperation has been completed after 10 years of negotiations.

The Sino-Russia Yamal LNG project was officially put into operation. In this project, PetroChina hold 20\% stake, Silk Road Fund hold 9.9\% stake, France total hold 20\% stake, Russia Novatec hold 50.1\% stake. On December 8, 2017, Russian President Vladimir Putin personally attended the first batch of LNG shipment celebrations and launched the loading button. The first phase of the Yamal LNG project was officially put into operation, with an annual production capacity of 5.5 million tons. After the completion of the third phase, the annual production capacity will reach 16.5 million tons and the condensate oil will be 1 million tons. According to the Sino-Russia contract, $54 \%$ of the project's output is sold to the Asian market, and about one-third of it will be supplied to the Chinese market.

In March 2006, China and Russia signed the Memorandum of Understanding on Gas Supply. Russia is committed to building two natural gas pipelines, and plans to export 60 billion- 80 billion cubic meters of natural gas to China every year for 30 years from 2011 . In June 2009, the Chinese and Russian heads of state signed the Memorandum of Understanding on Natural Gas Cooperation. In October 2009, China and Russia signed the "Framework Agreement on Russia's Export of Natural Gas to China". The Russian side promised to export nearly 70 billion cubic meters of natural gas to China via the Western and Eastern Lines from 2014 to 2015. The Western line is 30 billion cubic meters, and the Eastern line is 38 billion cubic meters.

In 2012 Gazprom and PetroChina confirm the intention to implement Western route. When in 2013 President Xi Jinping visited Russia, CNPC sign agreement with Gazprom. In October2013, Russia and CNPC reach a deal on the price calculation of gas supplied by Russia.

In 2013, PetroChina and Rosneft signed a memorandum of understanding (MoU) on upstream cooperation in Eastern Siberia and on establishing a joint venture company that would develop oil and gas fields, securing future ESPO demand China hold 49\% stake, Russia hold 51\% stake in the new joint venture company. This agreement represent breakthrough of Sino-Russia cooperation, because China capital has entered the upstream Russian energy industry and Russian overcome its psychological barrier toward China. Before that, it is hard for China to convince Russia permit China take part in the development of Far East energy. In 2017, Gazprom and PetroChina signed a Supplementary Agreement of the Sales and Purchase for Russian gas supplies via the eastern route, which specifies the starting date for the deliveries. According to this document, gas supplies to China via the Power of Siberia gas trunk line will begin in December 2019.

\section{Conclusions}

Although both China and Russia face the threat of US hegemony, the content and nature of threats vary. Russia's traditional geographical sphere of influence in Europe has been undermined by US-led NATO. As a counterattack, Russia conducted military intervention against Ukraine and Georgia in 2004 and 2013 respectively.

In retaliation, the United States took the lead in economic sanctions against Russia, Western European countries continued to reduce energy imports from Russia, and the United States used its shale oil technology to suppress oil prices. In order to ensure the safety of energy exports, Russia has changed its past practice of treating China as a potential strategic opponent and emphasizing relative returns. It regards China as a strategic partner and launches comprehensive and in-depth energy cooperation with China, allowing Chinese oil companies to enter the energy upstream and downstream industries. 
With regard to the rise of China, the United States has deep doubts. Cooperation and contain are the basis of the previous US administration China policy. China's oil and gas is largely dependent on importation, which makes China's energy security very vulnerable. In particular, the sea lane of energy transportation goes through the Malacca strait which is under the control of US Navy. In order to insure energy safety, China has made every effort to diversify its oil import channels. Russia, which is geographically adjacent to China and has common interests with China in international affairs, has become a reliable partner for China to ensure energy security. The "Indo-Pacific Strategy" proposed by the Trump administration regards China and Russia as adversary, emphasizes confrontation and zerosum approach. Thus, Sino-Russia energy security cooperation becomes more urgent.

Under the threat of US hegemony, China and Russia no longer overemphasized the relative interests and carried out comprehensive and in-depth energy cooperation. Russia has become China's largest energy importer, and Siberian oil pipelines to China have also been completed. The Russian oil industry has opened up upstream and downstream industries to Chinese capital. Russian energy has changed from its focusing on the European market in the past to the current Far East market. At present, in order to avoid energy risks, China has established an energy system that is independent of the West. With the strategic threat of US become more and more severe, the energy cooperation between China and Russia will be further enhanced.

\section{References}

1. B.Lo. Axis of convenience: Moscow, Beijing and the new geopolitics, Washington DC: Brookings (2008)

2. Raju G. C. Thomas. The Relationships among Energy, Security, and the Economy, in Raju G.C. Thomas \& Bennett Ramberg (eds ), Energy and Securily in the Industrializing World, The UniversitPress of Kentucky, pp 1-5 (1990)

3. Daniel Yergin. Energy Security in the 1990s, Foreign Affairs, Vol. 67, No.1, pp 111132 (1988)

4. Michael D. Swaine, A Counterproductive cold war with China. https:/www.foreignaffairs.com/articles/china/2018-03-02/counterproductive-cold-warchina. Accessed November 30, 2018.

5. Vladimir Putin. "Russia and changing world", https://sputniknews.com/analysis/20120227171547818/: Accessed November 30, 2018.

6. Panchangwei, 2018 nianguojiyoujiayuce: xiangtibodong zhendangshangyang, ouyajingji (Eurasian Economy, No.3, p. 9 (2018)

7. Tom Roseth. "Russia's energy relations with China: passing the strategic threshold?", Eurasian Geography and Economics, Vol. 58, No. 1, pp. 23-55 (2017)

8. Ronald Danneruther, "China and global oil: vulnerability and opportunity", International Affairs, Vol.87, No.6, p. 1358 (2011) 